\title{
Online Tax Filing-E-Government Service Adoption Case of Vietnam
}

\author{
Ngoc Long Lu${ }^{1}$, Van Trung Nguyen ${ }^{2}$ \\ ${ }^{1}$ Department of Business, Lac Hong University, Bien Hoa City, Vietnam \\ ${ }^{2}$ Lac Hong University, Bien Hoa City, Vietnam \\ Email: Lungochoanglan@gmail.com,trunglhu05@gmail.com
}

How to cite this paper: Lu, N.L. and Nguyen, V.T. (2016) Online Tax Filing-EGovernment Service Adoption Case of Vietnam. Modern Economy, 7, 1498-1504.

http://dx.doi.org/10.4236/me.2016.712135

Received: August 22, 2016

Accepted: November 15, 2016

Published: November 18, 2016

Copyright (c) 2016 by authors and Scientific Research Publishing Inc. This work is licensed under the Creative Commons Attribution International License (CC BY 4.0).

http://creativecommons.org/licenses/by/4.0/

\begin{abstract}
In this paper, we proposed a new model, which integrates two famous technology adoption models, the unified theory of acceptance and use of technology (UTAUT) model with Information system success model (IS success) to explanatory model of e-filing adoption. In particular, this study involved actual taxpayer $(\mathrm{N}=156)$ of specific users of e-filing system to examine the structural relationships among factors of: performance expectancy, effort expectancy, social influence, information quality, system quality, service quality, and intention to use by using SPSS 20. The results of this research show that e-filing intention to use of Vietnamese taxpayers is influenced by both six factors of the model. Hence, the conceptual model has served as a useful framework for academicians and government policy decision makers to evaluate and improve the e-filing system (e-government service) in Vietnam.
\end{abstract}

\section{Keywords}

UTAUT, IS Success Model, E-Filing, Vietnam

\section{Introduction}

Information communication technologies (ICTs) are changing the way that businesses are conducted, including government service. Government in emerging nations is relying on information technology as an important tool to improve the efficiency, cost, and quality of the government information and services provided to the citizens [1]. The rapid growth of investment from government to e-government service system or calling e-government has drawn attention to research on this area. In recent years, Vietnam is at the initial stages applying an e-government program. Same with other countries Vietnam also faces the problem of low level of citizen adoption of e-government services [2], which have been previously inaccessible. Carter and Belanger [3] have found 
that the acceptance of e-government system is not simply a technological concern. Thus, the success of this program is dependent upon citizen willingness to adopt this innovation.

Recently, the percentage of tax that taxpayers pay through e-filing system was still extremely lower compared with the traditional way in Vietnam. The purpose of this study is to examine the effect of electronic tax filing (e-filing) and payment system by applying the integration of an extended Unified Theory of Acceptance and Use of Technology (UTAUT) framework [4] with Information System success (IS success) [5] model on e-filing intention. Both of two models were used to study about customer acceptance, and each model was separately used to test the e-filing adoption; for example model UTAUT was used by Aziz and Idris [6] to identify which factors related to tax e-filing acceptability of Malaysian, or e-billing adoption of Indonesian [7]. Less research has been done on factors influencing the adoption of e-filing that consider not only technological issues (Information quality, system quality, service quality) but also personal adoption (performance expectancy, effort expectancy, social influence). Additionally, this research also concerned about the advantage and disadvantage of paying tax through e-filing system compared with traditional pay method. Hence, empirical studies about e-government adoption may help government to improve their understanding of taxpayers' adoption of e-file. Maybe the e-filing system will replace the traditional way in the near future in developing countries as Vietnam.

\section{Literature Review}

With the change and fast growth of ICTs has made government find out the way to satisfy the need of citizens by shift from traditional government to electronic government (e-government) [8]. The e-government concept involve novel forms of delivering and tailoring information and services more effectively and better serve citizens [9]. Laudon [10] said that e-government refer to the use of IT to improve the efficiency, cost, and quality of information and services provided by government. There is no universally accepted definition of the e-government concept [11] but the main rationale of e-government initiatives is offers flexible and convenient services focused on citizens needs [12]. Lee [13] said that e-government has the potential to enhance the relationship between the government and its citizens by more flexible, efficient interactions. Government invests huge amounts of money in these facilities when adopt e-government service, there is a need for research that investigate and understand the factors that influence or could encourage citizen to use e-services instated of traditional. E-government can lead greater convenience, cost reduction, revenue growth, and lowered time and effort for services [14]. However, when apply e-government system, it showed some problem such as complex and difficult to use. Most of the previous research has investigated issues of e-government in development countries, Baumgarten and Chui [15] found that in these countries more than 70 percent of taxpayers file was done by electronically system. On other hand, Chen [16] study IT adoption in different culture and e-government service in the developed and developing countries. There is still lack 
of research about e-filing adoption in Vietnam as a case study of e-filing system adoption in developing countries, with respondent is taxpayers. This research fulfill that gap when study e-filing adoption of taxpayers in Vietnam.

There is a large body of research study the adoption of ICT. Among the widely used theories and models explain user acceptance and adoption of technology, the UTAUT model, one of the key indicator and comprehensive model of information system intention. Venkatesh argued that this model explain 70 percent of technology acceptance. This model also was used and suggested by Al Awadhi et al. [17] and Carter et al. [18]. The theory UTAUT first time introduced in 2003 by synthesizing constructs from eight existing technology acceptance model. The comprehensive of UTAUT model have encouraged the current authors of this study to adopt and validate it in the context of e-filing system adoption. In addition to intention factors, information system quality is another significant factor. This was tested by IS success model with three factors, information quality, system quality, and service quality. A conceptual model of this research was developed based on UTAUT model and IS success model to test e-filing adoption by using a questionnaire as survey instrument.

\section{Methodology}

Building on the UTAUT framework [4] and IS success model [5], this study used the three constructs of UTAUT framework with four constructs of IS success model to examine taxpayer intention to use e-filing system. The research model in this study is constructed based on the six significant determinants of intention to use technology drawn from the UTAUT model and IS success model (i.e. performance expectancy, effort expectancy, social influence, information quality, system quality and service quality). The integration between UTAUT model and IS success model would assist government policy maker in understanding citizens' adoption with e-government system [4]. Recently, the percentage of taxpay using e-filing system is still extremely lower compare with traditional way in Vietnam. Therefore through a new model, this research will explain the taxpayer adoption. Furthermore, both of two model separately has been denoted as an important explaining customers intention to use the system via internet.

Do and Shih [19] found that quality of website or information system had a positive and significant impact on online customer intention. Related to willingness to use e-filing is the websites can be trusted with high information quality or not. Sichtmann [20] found that trust in high information quality from online websites positively affects purchase intentions. Wang and Emurian [21] argued that the quality of information and service is one of the most important constructs in determining whether people will pay online.

According to these reasons, the following research model is proposed (Figure 1).

\section{Data Collection and Analysis}

The survey instrument is a two part questionnaire. The first part uses nominal scales and captures demographic data while the second part of the questionnaire contains 


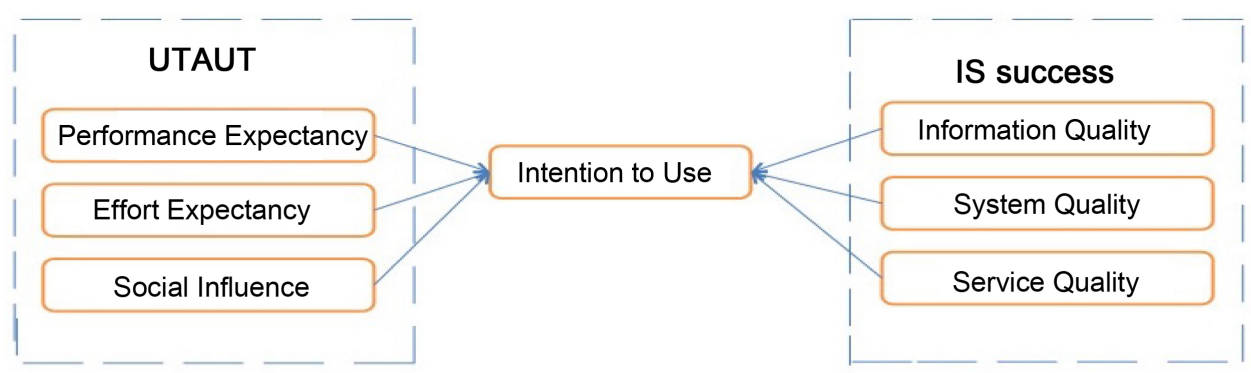

Figure 1. The conceptual model of this research.

items used to measure the independent variables. Multi-items used to measure each. A seven-point Likert Scale from strongly disagree to strongly agree was used to measure the items. A total of 200 questionnaires were mailed to the Head of the Accounting department of the randomly chosen company. Of the 156 questionnaire returned, 19 were not entirely completed by respondents, so were rejected. Hence 137 questionnaires were considered to use in this research.

Characteristic of respondents are including four major items: 1) gender, 2) age, 3) education, 4) monthly income. More than $79 \%$ are 36 - 55 years old. About $49 \%$ of respondents' incomes are more than ten thousand USD dollars per year. About $99.3 \%$ are graduated level. And most of them are often use internet for not only their work but also for the personal need for a long time (see Figure 2).

Both of the constructs in this study have direct effects on user intention. Hence, reliability of the instrument can be calculated by testing for internal consistency. According to Hair et al., [22] this study have high reliability which show by all of the factors have Cronbach's Alpha higher than 0.8 (see Table 1).

Prior conducting final survey and after final survey reliability of constructs was tested using and Amos 18.0. The second step was tested using multiple linear regression to test hypotheses. Table 2 illustrates the results of multigression testing that all of hypotheses were supported.

\section{Findings and Conclusion}

The major objectives of this study are to investigate tax payer's intention to use e-filing system by applying the UTAUT constructs with IS success constructs. Based on the result of study, the overall research findings firmly support the validity of the proposed model. These findings support the significance of integrate between UTAUT model and IS success model in predicting e-filing taxpayer intention. Compared with the traditional paying tax system, it is not surprise that known benefits connected with e-filing have a significant impact on taxpayers' intention to adopt the online channel. Consistent with recent research of Ahmad, Markkula, and Oivo [6] this study shows that three factors from UTAUT model play a significant role in taxpayer's intention, and then support the importance of identifying and understanding the influence of parents, bosses, co-workers, friends by using the same method to pay the tax.

There are significant relationships between UTAUT model and IS success model. It 


\section{Internet Using}

Experience

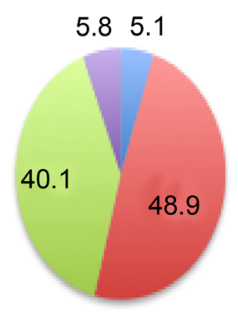

ICT System

Experience

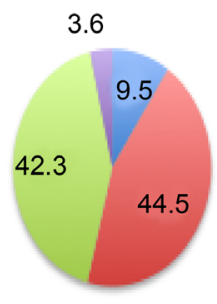

How many hours per week you use internet?

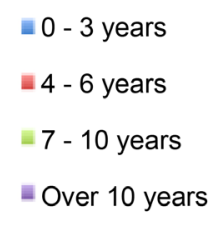

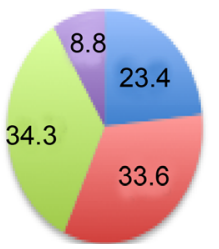

$0-10$ years

111 - 20 years

21 - 30 years

$=$ Over 30 years

Figure 2. Respondent's internet using frequency.

Table 1. Factor loading and reliability.

\begin{tabular}{|c|c|c|c|c|}
\hline Research Items & Factor Loading & Reliability & Eigen-value & Cumulative Explained \\
\hline Performance Expectancy & & 0.926 & 3.274 & $81.85 \%$ \\
\hline 1. PE1 & 0.90 & & & \\
\hline 2. PE2 & 0.939 & & & \\
\hline 3. PE3 & 0.924 & & & \\
\hline 4. $\mathrm{PE} 4$ & 0.854 & & & \\
\hline Effort Expectancy & & 0.936 & 3.360 & $84.00 \%$ \\
\hline 5. EE1 & 0.883 & & & \\
\hline 6. EE2 & 0.930 & & & \\
\hline 7. EE3 & 0.934 & & & \\
\hline 8. EE4 & 0.919 & & & \\
\hline Social Influence & & 0.930 & 3.311 & $82.76 \%$ \\
\hline 9. SI1 & 0.887 & & & \\
\hline 10. SI2 & 0.929 & & & \\
\hline 11. SI3 & 0.917 & & & \\
\hline 12. SI4 & 0.906 & & & \\
\hline Information Quality & & 0.938 & 4.012 & $80.23 \%$ \\
\hline 13. IQ1 & 0.869 & & & \\
\hline 14. IQ2 & 0.920 & & & \\
\hline 15. IQ3 & 0.938 & & & \\
\hline 16. IQ4 & 0.892 & & & \\
\hline 17. IQ5 & 0.857 & & & \\
\hline System Quality & & 0.898 & 2.494 & $83.12 \%$ \\
\hline 18. SQ1 & 0.905 & & & \\
\hline 19. SQ2 & 0.943 & & & \\
\hline 20. SQ3 & 0.887 & & & \\
\hline Service Quality & & 0.842 & 2.282 & $76.05 \%$ \\
\hline 21. SerQ1 & 0.874 & & & \\
\hline 22. SerQ2 & 0.897 & & & \\
\hline 23. SerQ3 & 0.845 & & & \\
\hline Intention to Use & & 0.919 & 2.584 & $86.13 \%$ \\
\hline 24. IU1 & 0.919 & & & \\
\hline 25. IU2 & 0.947 & & & \\
\hline 26. IU3 & 0.918 & & & \\
\hline
\end{tabular}


Table 2. Hypothesis testing.

\begin{tabular}{cccc}
\hline Hypothesis & t-value & P-value & Supported \\
\hline H1 (PE- > IU) & 3.357 & 0.001 & Yes $^{* * *}$ \\
H2 (EE- > IU) & 4.235 & 0.000 & Yes \\
H3 (SI- > IU) & 4.894 & 0.000 & Yes \\
H4 (IQ- > IU) & 4.800 & 0.000 & Yes \\
H5 (SQ- > IU) & 4.537 & 0.000 & Yes $^{* * *}$ \\
H6 (SerQ- > IU) & 3.932 & 0.001 & Yes $^{* * *}$ \\
\hline
\end{tabular}

means that the system quality, information quality and also service quality of the website have significant influence on taxpayers' intention to use the system. Many taxpayers are not willing to do e-filing because of the lack of trust to website or complexity of the system. Murray [23] commented that one of the barriers to e-filing is people being uncomfortable putting large volumes of personal data.

There are a lot of successful models, and constructs to effect on e-filing intention. This study contributes to literature by examining the two base models by integrating UTAUT with IS success. Presenting an important theory based on empirical test, the results of this study may help predict key factors of e-filing adoption. This study guided toward providing a better adoption of e-government information system through efiling system.

It is hardly possible to conduct a study that does not contain errors or an element of bias. The questionnaire of this study was collected in a short time period, and the sample size may not be adequate to represent the whole population as the sample may differ from the population simply. Therefore, since the samples are from different parts of Vietnam, this is a broad concept, which needs to represent more specific group for further deep research. Thus, we suggest that future research needs to have bigger sample size.

\section{References}

[1] Gupta, B., Dasgupta, S. and Gupta, A. (2008) Adoption of ICT in a Government Organization in a Developing Country: An Empirical Study. The Journal of Strategic Information Systems, 17, 140-154. http://dx.doi.org/10.1016/j.jsis.2007.12.004

[2] Bélanger, F. and Carter, L. (2008) Trust and Risk in E-Government Adoption. Journal of Strategic Information Systems, 17, 165-176. http://dx.doi.org/10.1016/j.jsis.2007.12.002

[3] Carter, L. and Bélanger, F. (2005) The Utilization of E-Government Services: Citizen Trust, Innovation and Acceptance Factors. Information Systems Journal, 15, 5-25. http://dx.doi.org/10.1111/j.1365-2575.2005.00183.x

[4] Venkatesh, V.M.D.D. (2003) User Acceptance of Information Technology: Toward a Unified View. MIS Quarterly, 27, 425-478.

[5] Delone, W.H. and McLean, E.R. (1992) Information System Success: The Quest for the Dependent Variable. Information Systems Research, 3, 60-95.

http://dx.doi.org/10.1287/isre.3.1.60

[6] Aziz, S.A. and Idris, K.M. (2012) The Determinants of Tax E-Filing Among Tax Preparers 
in Malaysia. World Journal of Social Sciences, 2, 182-188.

[7] Yusup, M., Hardiyana, A. and Sidharta, I. (2015) User Acceptance Model on E-Billing Adoption: A Study of Tax Payment by Government Agencies. Asia Pacific Journal of Multidisciplinary Research, 3.

[8] Ahmad, M.O., Markkula, J. and Oivo, M. (2012) Factors Influencing the Adoption of E-Government Services in Pakistan. European, Mediterranean \& Middle Eastern Conference on Information Systems, 118-133.

[9] Chen, J.V., Yen, D.C. and Chen, K. (2009) The Acceptance and Diffusion of the Innovative Smart Phone Use: A Case Study of a Delivery Service Company in Logistics. Information \& Management, 46, 241-248. http://dx.doi.org/10.1016/j.im.2009.03.001

[10] Laudon, K. and Laudon, J. (2009) Management Information Systems. 11th Edition, Prentice Hall, Upper Saddle River.

[11] Yildiz, M. (2007) E-Government Research: Reviewing the Literature, Limitations, and Ways Forward. Government Information Quarterly, 24, 646-665. http://dx.doi.org/10.1016/j.giq.2007.01.002

[12] Moon, M.J. (2002) The Evolution of E-Government among Municipalities: Rhetoric or Reality? Public Administration Review, 62, 424-433. http://dx.doi.org/10.1111/0033-3352.00196

[13] Lee, S., Tan, X. and Trimi, S. (2005) Current Practices of Leading E-government Countries. Communications of the ACM, 48, 99-104. http://dx.doi.org/10.1145/1089107.1089112

[14] UN (2010) United Nation E-Government Survey. http://unpan1.un.org/intradoc/groups/public/documents/UN-DPADM/UNPAN038853.pdf

[15] Baumgarten, J. and Chui, M. (2009) E-Government 2.0. McKinsey on Government, 4, 2631.

[16] Chen, Y.N., et al. (2006) E-Government Strategies in Developed and Developing Countries: An Implementation Framework and Case Study. Journal of Global Information Management, 14, 23-46. http://dx.doi.org/10.4018/jgim.2006010102

[17] AlAwadhi, S. and Morris, A. (2009) Factors Influencing the Adoption of E-Government Services. Journal of Software, 4, 584-590. http://dx.doi.org/10.4304/jsw.4.6.584-590

[18] Carter, L., Christian Shaupp, L., Hobbs, J. and Campbell, R. (2011) The Role of Security and Trust in the Adoption of Online Tax Filing. Transforming Government: People, Process and Policy, 5, 303-318. http://dx.doi.org/10.1108/17506161111173568

[19] Do, T.H.N. and Shih, W. (2016) The Integration between the UTAUT with IS Success Model in Case of Online Hotel Booking User Acceptance. Research Journal of Commerce and Behavioural Science, 5, 25-36.

[20] Sichtmann, C. (2007) An Analysis of Antecedents and Consequences of Trust in a Corporate Brand. European Journal of Marketing, 41, 999-1015. http://dx.doi.org/10.1108/03090560710773318

[21] Wang, T.D. and Emurian, H.H. (2005) An Overview of Online Trust: Concepts, Elements, and Implications. Computers in Human Behavior, 21, 105-125. http://dx.doi.org/10.1016/j.chb.2003.11.008

[22] Hair, J.F., Black, W.C., Babin, B.J., Anderson, R.E. and Tatham, R.L. (2006) Multivariate Data Analysis. Prentice Hall, Upper Saddle River.

[23] Murray, T. (2010) As E-Filing Turns 20, IRS Trying to Win over Remaining Third of Taxpayers from Paper Returns. www.cleveland.com/business/index.ssf/2010/2002/as e-filing turns $2020 \mathrm{irs}$ tryin.html 
Submit or recommend next manuscript to SCIRP and we will provide best service for you:

Accepting pre-submission inquiries through Email, Facebook, LinkedIn, Twitter, etc.

A wide selection of journals (inclusive of 9 subjects, more than 200 journals)

Providing 24-hour high-quality service

User-friendly online submission system

Fair and swift peer-review system

Efficient typesetting and proofreading procedure

Display of the result of downloads and visits, as well as the number of cited articles

Maximum dissemination of your research work

Submit your manuscript at: http://papersubmission.scirp.org/

Or contact me@scirp.org 